AGRARIS: Journal of Agribusiness and Rural Development Research

Vol. 6 No. 1 January-June 2020

Article History:

Submitted : June $20^{\text {th }}, 2019$

Accepted : March 15th, 2020
Rokhani1,3, Mohammad Rondhi'2,3*, Ebban Bagus Kuntadi 2,3, Joni Murti Mulyo Aji2,3, Anik Suwandari ${ }^{2,3}$, Agus Supriono ${ }^{2,3}$, Triana Dewi Hapsari ${ }^{2,3}$

${ }^{1}$ Department of Agricultural Extension, Faculty of Agriculture, University of Jember

${ }^{2}$ Department of Agribusiness, Faculty of Agriculture, University of Jember ${ }^{3}$ Institutional Economic for Agribusiness Reforms and Development (INFRARED) Research Group, University of Jember

*) Correspondence email: rondhi.faperta@unej.ac.id

\title{
Assessing Determinants of Farmer's Participation in Sugarcane Contract Farming in Indonesia
}

\author{
DOI: https://doi.org/10.18196/agr.6187
}

\begin{abstract}
The integrated value chain is a prerequisite for the successful industrialization of the agricultural sector. Contract farming $(\mathrm{CF})$ is a useful instrument to integrate the agricultural value chain in developing countries such as Indonesia. The purpose of this study was to identify the determinants of farmer participation in sugarcane contract farming. The data utilized in this study was obtained from the Indonesian Plantation Farm Household Survey 2014 for Sugarcane. The data consists of 8.831 farmers distributed in 8 provinces. Logistic regression was used to estimate the determinants of farmer participation in sugarcane CF. The result shows that age, education, and type of cultivated land negatively affect farmer participation in sugarcane CF. Meanwhile, land tenure, cultivation area, cropping system, certified seed, membership in a cooperative, access to extension services, and membership in farmer's association positively affect farmer participation in sugarcane CF. The policy implication for increasing farmer participation in CF is to intensify the information of CF to the farmer with a large cultivation area. Since these farmers tend to participate in CF to anticipate marketing risks.
\end{abstract}

Keywords: contract farming, sugarcane, Indonesian plantation farm household survey

\section{INTRODUCTION}

The integration of agricultural value chains is one of the prerequisites for the success of agricultural industrialization. An integrated value chain enables a smooth flow of goods and information so that the agricultural sector can respond and meet market needs precisely and quickly (OECD/WTO, 2013). Contract farming (CF) is an instrument used to integrate agricultural value chains since it solves high transaction costs, limited access to finance, limited regulatory transparency, and issues related to value chain governance (Bellemare \& Lim, 2018). CF aims to link small-scale farmers to high-value markets (exports and supermarkets) or processing companies. Linking small-scale farmers to export markets and supermarkets is the most effective alternative to reduce poverty in developing countries (World Bank, 2008). 
Empirically, participation in CF has proven to be beneficial for farmers and companies. Participation in CF reduces the risk of farming for small-scale farmers in India (Mishra, Kumar, Joshi, D'Souza, \& Tripathi, 2018). CF also plays a role in minimizing the costs of providing farm capital for farmers and labor costs for companies (Oya, 2012). For farmers, the main benefits of CF are increased income and welfare, such as contract farmers in Ghana, India, Madagascar, Mozambique and Nicaragua (Barrett et al., 2012), corn farmers, rice farmers and broiler breeders in Indonesia (Simmons, Winters, \& Patrick, 2005), and contract farmers in several other developing countries (Bellemare \& Bloem, 2018). Moreover, $\mathrm{CF}$ is the beginning of a structural transformation of the agricultural sector because it encourages the transition from semi-subsistence agriculture to commercial agriculture (Barrett, Christiaensen, Sheahan, \& Shimeles, 2017). These results indicate the importance of farmer participation in CF for the economy of developing countries, such as Indonesia.

The rate of participation of CF in Indonesia is quite low compared to developed countries. The rate of participation of CF in Indonesia based on sub-sectors and commodities are livestock subsector: broiler 55.65\%; dairy 12.15\%; beef cattle 0.28\% (BPS, 2014), horticulture subsector: cayenne pepper $7.67 \%$; red chilies $8.03 \%$; shallots $3.05 \%$; mango 6.24\%; banana 5.09\% (BPS, 2015a), plantation subsector for all commodities $2.9 \%$ (BPS, 2015b). This figure is relatively low when compared to developed countries like the United States, where the rate of participation in CF reaches 97\% (MacDonald \& Korb, 2012). Under these conditions, increasing the participation in CF for strategic agricultural commodities has a vital role in agricultural industrialization in Indonesia.

One of the strategic agricultural commodities in Indonesia is sugar cane. Sugar cane is the primary raw material for the Indonesian sugar industry. Currently, the Indonesian sugar industry is only able to supply 2.19 million tons of sugar out of a total demand of 5.7 million tons (Iswara, 2017). Accelerating the process of industrialization of sugar cane plantations is a crucial step to achieve national sugar self-sufficiency. Increasing the participation of sugar cane farmers in CF is a possible solution to accelerate this process. The participation of sugarcane farmers in CF has several positive impacts. For example, CF between Jati Tujuh Sugar Mills ( PG ) and sugar cane farmers in West Java increases farmers' empowerment through access to capital, the provision of production facilities, and marketing (Fadilah \& Sumardjo, 2011), CF also increase production and profits per hectare for sugar cane farmers in Jember (Lestari, Fauzi, Hutagaol, Hidayat, \& Hidayat, 2016). An effective strategy is needed to increase farmer participation in CF. The strategy needs to be based on factors that determine sugar cane farmer's participation in CF.

The majority of research on sugar cane CF are case studies (Agiesta, Widjaya, \& Hasanuddin, 2017; Fadilah \& Sumardjo, 2011; Lestari et al., 2016). These researches can provide a detailed picture of the conditions of CF in an area. However, this research is insufficient as the basis to formulate policies on a national scale. Based on these conditions, this study aims to identify the factors that effect sugar cane farmer's participation in CF in Indonesia. Using data from the Sugarcane Plantation Farm Household Survey with a total 
sample of 8831 farmers, this study provides a nationally-representative analysis that suitable for the formulation of national sugar cane policies.

\section{METHODS}

Data

The data used in this study is the data of the 2014 Indonesian Plantation Farm Household Survey (IPFHS) of sugarcane produced by the Central Statistics Agency (BPS) of the Republic of Indonesia. IPFHS is part of the 2013 Agriculture Census (ST2013) and covers the entire territory of Indonesia. Plantation commodities in the IPFHS are divided into two categories, national plantation commodities (cocoa, rubber, palm oil, coffee) and provincial plantation commodities. Sugar cane is a provincial plantation commodity. The IPFHS field data were collected from May 26 to July 7, 2014 (Sub-Directorate of Plantation Crop Statistics, 2016). Figure 1 shows the distribution of smallholder sugarcane farmers respondents and contract-farmer in IPFHS.

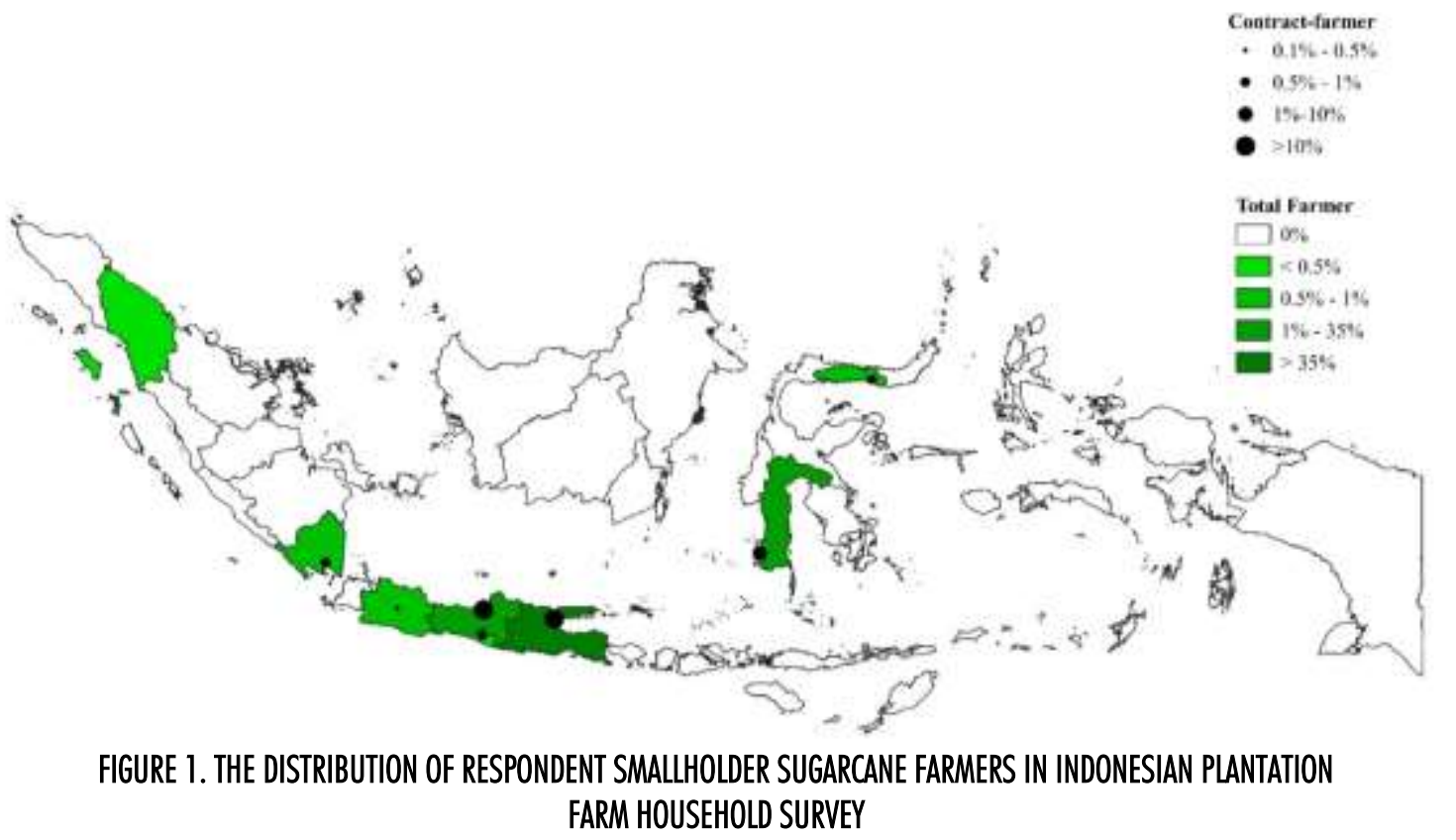

The sampling method used in the IPFHS was two-stage random sampling. The first step is taking random sample blocks from the census block framework. The systematic proportional to size was used in the selection of sample blocks. The intended size for each census block is the number of plantation farm households (PFH). The framework for the selection of sample blocks is twofold, namely ordinary census blocks and census blocks containing the results of ST2013, which have been stratified by primary crop. The eligible sample block is a census block that has a minimum of $10 \mathrm{PFH}$. After the sample block is determined, the second step is to determine the PFH sample. Systematic sampling was used to determine the PFH sample with consideration of the types of primary plantation crops, the amount of planting area in $\mathrm{m}^{2}$, and the number of plants produced at the time of enumeration. The framework for PFH selection is the list of PFH in selected blocks that have 
been sorted by the planting area. The eligibility of the PFH sample for sugar cane is $\mathrm{PFH}$ with a minimum planting area of $650 \mathrm{~m}^{2}$ (BPS, 2015c).

TABLE I DESCRIPTIVE STATISTICS OF RESEARCH DATA

\begin{tabular}{|c|c|c|c|c|}
\hline Variable & Code & Information & Average and Frequency & $\begin{array}{c}\text { Elementary } \\
\text { school }\end{array}$ \\
\hline \multicolumn{5}{|c|}{ Dependent Variable } \\
\hline Participation in contract farming & $Y$ & $\begin{array}{l}\text { Binary category variables ( } 0=\text { independent } \\
\text { farmers; } 1=\text { contract farmers) }\end{array}$ & $\begin{array}{l}1: 3036(34.4 \%) \\
0: 5795(65.6 \%)\end{array}$ & \\
\hline \multicolumn{5}{|c|}{ Independent Variable } \\
\hline Age & $\mathrm{Xl}$ & Age of sugar cane PFH head (years) & 51.59 & 11.82 \\
\hline Education & $x 2$ & Length of formal education (year) & 5.85 & 4.46 \\
\hline Gender & X3 & Dummy Variable $(1=$ Male, $0=$ Female $)$ & $\begin{array}{l}1: 7974(90.3 \%) \\
0: 857(9.7 \%)\end{array}$ & \\
\hline Land Tenure & $X 4$ & $\begin{array}{l}\text { Dummy Variable }(1=\text { Self-owned, } 2= \\
\text { Rent, } 3=\text { Sharecropping) }\end{array}$ & $\begin{array}{l}1: 7163(81.1 \%) \\
2: 1098(12.4 \%) \\
3: 570(6.5 \%)\end{array}$ & \\
\hline Land area & $x 5$ & Sugar cane planting area (ha) & 0.9 & 3.15 \\
\hline Land Type & $x 6$ & $\begin{array}{l}\text { Dummy variable }(1=\text { Paddy farmland, } 0 \\
=\text { Non paddy farmland })\end{array}$ & $\begin{array}{l}\text { 1: } 3006(34 \%) \\
0: 5825(66 \%)\end{array}$ & \\
\hline Planting System & X7 & $\begin{array}{l}\text { Dummy variable, planting system applied to } \\
\text { sugar cane }(1=\text { Single, } 2= \\
\text { Intercropping, } 3=\text { Mixed })\end{array}$ & $\begin{array}{l}1: 8740(98.9 \%) \\
2: 58(0.7 \%) \\
3: 33(0.4 \%)\end{array}$ & \\
\hline Seeds & X8 & $\begin{array}{l}\text { Dummy variable, type of seed used ( } 1= \\
\text { Certified seed, } 0=\text { Uncertified seed) }\end{array}$ & $\begin{array}{l}1: 1430(16.2 \%) \\
0: 7401(83.8 \%)\end{array}$ & \\
\hline Dependency ratio & X9 & $\begin{array}{l}\text { The ratio between the number of sugar cane } \\
\text { farmers in the family and the number of } \\
\text { family members }\end{array}$ & 0.32 & .17 \\
\hline Membership in KUD / Cooperatives & $\times 10$ & $\begin{array}{l}\text { Dummy variable ( } 1=\text { KUD / Cooperative } \\
\text { member, } 0=\text { Not a KUD / Cooperative } \\
\text { member) }\end{array}$ & $\begin{array}{l}1: 1347(15.3 \%) \\
0: 7484(84.7 \%)\end{array}$ & \\
\hline Access to agricultural extension & X11 & $\begin{array}{l}\text { Dummy variable ( } 1=\text { getting counseling, } 0 \\
=\text { not getting counseling) }\end{array}$ & $\begin{array}{l}1: 1383(15.7 \%) \\
0: 7448(84.3 \%)\end{array}$ & \\
\hline $\begin{array}{l}\text { Membership in the Sugar Cane Farmers } \\
\text { Association }\end{array}$ & $\mathrm{X} 12$ & $\begin{array}{l}\text { Dummy Variable ( } 1=\text { Associate member, } 0 \\
=\text { Non-associate member) }\end{array}$ & $\begin{array}{l}1: 466(5,3) \\
0: 8365(94.7 \%)\end{array}$ & \\
\hline \multicolumn{5}{|c|}{ Distribution of sample farmers } \\
\hline Distribution of sugar cane RTUP & & $\begin{array}{l}\text { Distribution of sugarcane RUTP in each } \\
\text { province ( } 1=\text { North Sumatra, } 2= \\
\text { Lampung, } 3=\text { West Java, } 4=\text { Central } \\
\text { Java, } 5=\text { Yogyakarta, } 6=\text { East Java, } 7 \\
=\text { South Sulawesi, } 8=\text { Gorontalo) }\end{array}$ & $\begin{array}{l}1: 3(0.03 \%) \\
2: 88(0.99 \%) \\
3: 75(0.84 \%) \\
4: 3146(35.6 \%) \\
\text { 5: } 0.5(12.2 \%) \\
\text { 6: } 5281(59.8 \%) \\
7: 104(1.2 \%) \\
8: 86(1.0 \%)\end{array}$ & \\
\hline
\end{tabular}

Source: 2014 Indonesian Plantation Farm Household Survey

In total, 8831 sugar cane PFHs were interviewed in the IPFHS. These farmers are located in the primary province of sugar cane production. Table 1 contains the distribution of PFH and descriptive statistics of the variables. In general, sugar cane farmers in Indonesia are on Java island with the most substantial proportion located in East Java and Central Java, accounting for $59.8 \%$ and $35.6 \%$, respectively (see figure 1). Other regions with the number of sugarcane farmers sorted from the largest to the smallest proportion are Yogyakarta, South Sulawesi, Gorontalo, Lampung, West Java, and North Sumatra. 
Based on the information in Table 1, the number of sugarcane farmers participating in CF is 34.4\%. This amount is much higher compared to CF participation in the plantation sector, which is only $2.9 \%$. The average sugar cane farmer is 51.59 years old, with an average level of education being elementary school (average length of education is 5.85 years). The majority of sugarcane farmers are men, with only $9.7 \%$ who are female farmers. The average dependency ratio of sugar cane PFH is 0.32 , which means that each sugar cane farmer has an average of two dependents.

Most of the sugarcane farmers cultivated their land (81.1\%), while the rest cultivated on leased land (12.4\%) and sharecropping (6.5\%). Most farmers cultivated sugar cane on nonpaddy farmland $(66 \%)$ while the rest cultivated on paddy farmland. Sugarcane planting generally cultivated by single cropping system, and a small portion is cultivated by intercropping and mixed cropping. The use of certified seed is still relatively low, and most farmers still use uncertified seed.

The rate of participation of sugarcane farmers in agricultural extension, cooperatives, and agricultural associations is still relatively low. The number of sugar cane farmers in Indonesia who are members of the KUD / Cooperative is $15.3 \%$. Similarly, sugar cane farmers with access to an agricultural extension are $15.7 \%$. The membership of sugarcane farmers in the farmers association has a meager value of $5.3 \%$.

\section{Analytical Procedure}

Logistic regression was used to estimate the factors affecting farmer's decision to participate in CF. Logistic regression is a regression method used to estimate the effect of several independent variables on the independent variables in the form of binary variables (Field, 2005). Twelve independent variables were expected to affect farmer's participation in CF. The logistic regression model is shown in Equation 1.

$$
\operatorname{Logit}(P)=\beta_{0}+\sum_{i=1}^{12} \beta_{i} x_{i}+\varepsilon
$$

Maximum Likelihood Estimation (MLE) method was used to estimate the model. Omnibus Test of Model Coefficients and pseudo-R2 values were used to test the robustness of the model. The effect of each independent variable was estimated using the regression coefficient and the odd-ratio.

\section{RESULT AND DISCUSSIONS}

\section{Logistic regression estimation results}

The results of logistic regression analysis show that the estimated model is robust. There are ten of twelve independent variables that have a significant effect on farmers' decisions to participate in CF. The logistic regression model has a Chi-square value significant at $1 \%$ level. It shows that adding independent variables in the model significantly increases the ability of the model to explain the variance of farmers' decisions to participate in CF.

Farmer's age and education have a negative effect and significant to the decision of sugarcane farmers to participate in $\mathrm{CF}$, while the gender variable does not have a significant effect. Land tenure has a positive and significant effect on the farmer's participation in CF, 
while farmers who manage the production on sharecropping land tend not to participate in CF. The land area has a positive and significant effect on farmer's participation in CF. Meanwhile, farmers who cultivate sugar cane on paddy fields tend not to contract. Single cropping and intercropping systems have a positive effect on farmer's participation in CF while the mixed cropping system has a negative effect.

TABLE 2 LOGISTIC REGRESSION ESTIMATION RESULTS

\begin{tabular}{lccc}
\hline \multicolumn{1}{c}{ Variable } & Coefficient & Sig. & Odds Ratio \\
\hline Intercept & $-2,965$ & $.001^{* * *}$ & 0.052 \\
Age & $-0,014$ & $0,000^{* * *}$ & .986 \\
Education & $-0,047$ & $0,000^{* * *}$ & .954 \\
Gender & 0.090 & $0.313 \mathrm{~ns}$ & 1,094 \\
Land Ownership & & & 1,587 \\
$\quad$ One's own & 0.462 & $0,000^{* * *}$ & 1,693 \\
$\quad$ Rent & 0.527 & $0,000^{* * *}$ & 1,126 \\
Land area & .119 & $0,000^{* * *}$ & 0.865 \\
Land Type (Paddy farmland) & $-0,145$ & $0,000^{* * *}$ & 8,709 \\
Planting System & & & 11,000 \\
$\quad$ Single & 2,164 & $0.009^{* * *}$ & 2,297 \\
$\quad$ Intercropping & 2,398 & $0.007^{* * *}$ & 0.795 \\
Seedlings (Certified) & 0.832 & $0,000^{* * *}$ & 4,651 \\
Dependency ratio & -0.230 & $0,131 \mathrm{~ns}$ & 2,788 \\
Membership in KUD / Cooperatives (Members) & 1,537 & $0,000^{* * *}$ & 5,759 \\
Access to agricultural extension & 1,025 & $0,000^{* * *}$ & \\
Membership in the Sugar Cane Farmers Association $\quad$ Model Robustness & 1,751 & $0,000^{* * *}$ & \\
Omnibus Tests of Model Coefficients (Chi-square) & & & \\
Cox and Snell R2 & 1952,186 & $0,000^{* * *}$ & \\
Nagelkerke R2 & .198 & & \\
N & 0.274 & & \\
\hline Note. *** **, and * states are significant at 1\%, 5\% and 10\% respectively & 8831 & & \\
\hline
\end{tabular}

Note: ${ }^{* * *},{ }^{* *}$, and ${ }^{*}$ states are significant at $1 \%, 5 \%$, and $10 \%$ respectively.

Source: Author's analysis, 2019

\section{Discussion}

The logistic regression estimation results show that age has a negative effect with an odd-ratio value of 0.986 . It shows that the probability for farmers to contract decreased by $1.14 \%$ in line with the addition of age by one year. These results indicate that contract farmers tend to be younger than independent farmers. The average age of sugar cane contract farmers is 50.81 years, while independent sugar cane farmers are 52 years. Age is a factor that describes the experience and ability of farmers. This result is different from the results of research by corn and potato contract farmers in Okara District, Pakistan, where farmers who participated in CF tended to be older because the partner companies preferred farmers with longer farming experience (Khan, Nakano, \& Kurosaki, 2019). The reason for this difference is because age is not a company priority in choosing farmers. Also, young farmers are more proactive in gaining institutional access (Rondhi, Pratiwi, Handini, Sunartomo, \& Budiman, 2018).

Farmer education has a negative impact with an odd-ratio of 0.954 , which shows that sugar cane farmers with high formal education tend not to participate in CF. Several studies indicate that farmer education tends not to have a significant effect on farmers' decisions to participate in CF. A study on corn and potato CF in Pakistan shows that education does not 
have a statistically significant effect (Khan et al., 2019). Similar results were also found in broiler CF in China (Mao, Zhou, Ifft, \& Ying, 2019). In general, the sugarcane farmers in Indonesia have low formal education. Most farmers (71.2\%) had the highest education at the elementary school level, $25.5 \%$ had junior/senior high school education, while less than 5\% had high education. Meanwhile, the gender of farmers does not have a significant impact on farmers' decisions in partnering.

The land aspect consists of three factors: land ownership, type, and area. Land ownership is a categorical variable with three categories, owned land, rented land, and sharecropping. Estimation results show that farmers who cultivate sugar cane on owned and rented land tend to participate in CF with odd-ratio values of 1.587 and 1.693. Land ownership status has an important role in farm decision making, such as decisions related to the use of production inputs (Rondhi \& Adi, 2018), land management (Rondhi et al., 2018), and adaptation and mitigation of the impacts of climate change (Rondhi, Khasan, Mori, \& Kondo, 2019). Land ownership status determines the incentives that farmers will get from farming decisions taken. The security of land tenure will encourage farmers to make farming decisions that have the probability of providing benefits. Thus, farmers who manage their owned and leased land tend to participate in CF because they have secure land tenure.

The land area has a positive effect on farmers' decision to participate in CF with an odd-ratio value of 1.126 . It indicates that the probability for farmers to partner will increase by $12.6 \%$ along with the addition of 1 hectare of land. Similar results were also found in research on partnership oil palm plantations in Ghana, where large tracts of land tend to join CF to minimize price risk (Väth, Gobien, \& Kirk, 2019). The area of land affects the risk of farming faced by farmers. An increase in the land area will increase farming production, which then increases the value of a significant loss if the price at harvest is low. This risk can be anticipated by participating in CF, where farmers will get certainty about the sale of their products. Meanwhile, farmers who cultivate sugar cane on paddy fields tend not to partner. Odd-ratio value of paddy land is 0.865 , which shows that farmers who cultivate sugar cane on paddy fields have a $14.5 \%$ less probability of contracting compared to farmers who cultivate sugar cane on non-paddy fields.

The planting system has a positive effect on a farmer's participation in CF. The planting system is a categorical variable with two criteria, namely single cropping and intercropping. Based on the odd-ratio value, farmers who implement a single cropping system have a smaller probability of participating in CF. The odd-ratio value of a single planting system is 8.7 , while the intercropping system has an odd-ratio value of 11 . Intercropping systems can be applied to sugarcane and food crops. The application of this system can provide additional results in the first four months of planting sugar cane (BALITTAS, 2016). Meanwhile, the use of certified cane seed has a positive effect on farmers' probability to partner. Farmers who use certified seeds have a $120 \%$ greater chance of participating in CF. Furthermore, the use of certified seed increases sugar cane farm productivity and technical efficiency in Indonesia (Suwandari et al., 2020). These results are in line with the function of 
$\mathrm{CF}$ as an instrument for farmers to obtain quality farm inputs, including seeds (Mishra, Kumar, Joshi, \& D'souza, 2016).

Institutional factors have a positive and significant effect on farmers' participation in CF. Membership in cooperatives has an odd-ratio value of 4.651, which shows that sugarcane farmers who are members of cooperatives have a 4.651 times greater probability of participating in CF than those who are not members of cooperatives. A study on pineapple contract farmers in Ghana shows that success in CF is determined by self-efficacy and social capital owned by farmers towards CF. Both of these factors are strongly affected by the membership of farmers in cooperatives, where farmers who are active in cooperative membership have the confidence and strong social capital to partner (Wuepper \& Sauer, 2016).

Access to agricultural extension also has a positive effect on farmers' participation in CF with an odd-ratio value of 2.788. Farmers who have access to extension services have a probability of participating in CF 2.788 times greater than farmers with no access to extension services. However, access to the extension might be associated with farmers' participation in CF. As in the organic rice CF in India, where extension services are one of the benefits received by farmers from CF (Mishra et al., 2018). The similar results were also found in broiler CF (Rondhi, Aji, Khasan, Putri, \& Yanuarti, 2020) and tobacco CF in Indonesia (Rondhi et al., 2020).

Membership in sugarcane farmers associations has a positive effect on farmers' farmers' participation in CF with an odd-ratio value of 5.759. As is the case with membership in cooperatives, membership in sugarcane farmers associations strengthens social capital and farmer confidence. Farmers' associations in certain cases are implementing CF, such as the corn CF in Ghana formed by the corn farmers association called Masara (Lambrecht \& Ragasa, 2018). So that association members have a great probability of participating in CF. The association also acts as a price negotiator between farmers and processing plants, as happened between rice farmers and rice mills in Senegal (Soullier \& Moustier, 2018). The same condition also occurs in Indonesia between the Indonesian People's Sugar Cane Farmers Association (APTRI), which is an organization that represents farmers in negotiating prices and policies related to sugar cane.

Based on the discussion above, there are factors determining farmer's participation in $\mathrm{CF}$ and factors that are the result of CF. The determinants of CF are factors that encourage farmers to participate in CF, such as land area. Land area is closely related to the risks faced by farmers, especially price risk.Small-scale farmers maximize profits by exploiting the selling price. Small-scale farmers get maximum profits when prices are high, and a small loss when prices are low, due to the small amount of sugarcane production. Meanwhile, price speculation is difficult for farmers with large cultivation areas due to the high risk of loss during low prices.

Other factors that determine farmer's participation in CF include age, education, land ownership, membership in cooperatives, and farmers associations. Meanwhile, access to agricultural extension is a result of farmer's participation in CF because extension service is 
one of the facilities provided by CF. Another factor which is the result of CFis the certified seed and planting system. Both of these factors are the result because CF facilitates farmers to get access to quality farming inputs and a good planting system.

\section{CONCLUSIONS}

This study aims to identify the factors that affect the decision of sugar cane farmers in Indonesia to participate in CF. Based on the estimation results of logistic regression, there are ten of the twelve factors that have a significant effect on the decision of farmers to participate in CF. Factors that have positive and statistically significant effects include land ownership, land area, planting system, certified seedlings, membership of cooperatives / KUD, access to agricultural extension, and membership in farmer associations. Meanwhile, factors that negatively affected include age, education, and type of agricultural land. A factor that strongly encourages farmers to participate in CF is land area because the price risk increases with the increase in land area.

\section{ACKNOWLEDGEMENTS}

We are grateful to the University of Jember Research and Community Services (LP2M) for funding this research under the 2019 Research Group Research Grant (KeRis), Grant Number: 1394/UN25.3.1/LT/2019.

\section{REFERENCES}

Agiesta, V., Widjaya, S., \& Hasanuddin, T. (2017). Faktor-Faktor Yang Berhubungan Dengan Keputusan Petani Beralih Kemitraan Dalam Berusahatani: Kasus Petani Kemitraan Tebu Di PT Gunung Madu Plantataions Beralih Ke Kemitraan Ubi Kayu Di Pabrik Bumi Waras. JIIA, 5(1), 76-83.

BALITTAS. (2016). Sistem Tanam Tebu Juring Ganda Dengan Benih Ganda. Retrieved June 10, 2019, from Info Teknologi website: http://balittas.litbang.pertanian.go.id/index.php/id/component/content/article/60info-teknologi/377-sistem-tanam-tebu-juring-ganda-dengan-benih-ganda?Itemid=101

Barrett, C. B., Bachke, M. E., Bellemare, M. F., Michelson, H., Narayanan, S., \& Walker, T. F. (2012). Smallholder Participation in Contract Farming: Comparative Evidence from Five Countries. World Development, 40(4), 715-730.

Barrett, C. B., Christiaensen, L., Sheahan, M., \& Shimeles, A. (2017). On the structural transformation of rural Africa. Journal of African Economies, 26, i11-i35. https://doi.org/10.1093/jae/ejx009

Bellemare, M. F., \& Bloem, J. R. (2018). Does contract farming improve welfare? A review. World Development, 112, 259-271. https://doi.org/10.1016/j.worlddev.2018.08.018

Bellemare, M. F., \& Lim, S. (2018). In All Shapes and Colors: Varieties of Contract Farming. Applied Economic Perspectives and Policy, 40(3), 379-401. https://doi.org/10.1093/aepp/ppy019

BPS. (2014). Analisis Rumah Tangga Usaha Peternakan di Indonesia (H. Marhaeni, Ed.). Jakarta: 
Badan Pusat Statistik.

BPS. (2015a). Analisis Rumah Tangga Usaha Hortikultura di Indonesia (H. Marhaeni, Ed.). Jakarta: Badan Pusat Statistik.

BPS. (2015b). Analisis Rumah Tangga Usaha Perkebunan di Indonesia (H. Marhaeni, Ed.). Jakarta: Badan Pusat Statistik.

BPS. (2015c). Pedoman Teknis BPS Provinsi/BPS Kabupaten/Instruktur Nasional Survei Penyusunan Diagram Timbang Nilai Tukar Petani 18 Kabupaten (SPDT NTP) 2015. Retrieved from https://sirusa.bps.go.id/webadmin/pedoman/2015_3400_ped_Pedoman Teknis BPS Provinsi.pdf

Fadilah, R., \& Sumardjo. (2011). Analisis Kemitraan antara Pabrik Gula Jatitujuh dengan Petani Tebu Rakyat di Majalengka, Jawa Barat. Sodality: Jurnal Transdisiplin Sosiologi, Komunikasi, Dan Ekologi ManusiaJurnal Transdisiplin Sosiologi, Komunikasi, Dan Ekologi Manusia, 05(02), 159-172.

Field, A. (2005). Discovering Statistics Using SPSS. In Ism Introducing Statistical Methods (Vol. 2nd). https://doi.org/10.1016/j.landurbplan.2008.06.008

Iswara, P. (2017). 2017, Konsumsi Gula Diperkirakan 5,7 Juta Ton. Retrieved January 23, 2019, from Demografi website: https://databoks.katadata.co.id/datapublish/2017/07/11/2017-konsumsi-guladiperkirakan-57-juta-ton

Khan, M. F., Nakano, Y., \& Kurosaki, T. (2019). Impact of contract farming on land productivity and income of maize and potato growers in Pakistan. Food Policy, (April), 112. https://doi.org/10.1016/j.foodpol.2019.04.004

Lambrecht, I. B., \& Ragasa, C. (2018). Do development projects crowd-out private sector activities? Evidence from contract farming participation in Northern Ghana. Food Policy, 74(June 2017), 9-22. https://doi.org/10.1016/j.foodpol.2017.11.001

Lestari, E. K., Fauzi, A., Hutagaol, M. P., Hidayat, A., \& Hidayat, A. (2016). Keuntungan Petani Tebu Rakyat Melalui Kemitraan di Kabupaten Jember. Buletin Tanaman $\begin{array}{llllll}\text { Tembakau, Serat } & \mathcal{G} & \text { Minyak } & \text { Industri, } & 7(2), & 79 .\end{array}$ https://doi.org/10.21082/bultas.v7n2.2015.79-89

MacDonald, J. M., \& Korb, P. (2012). Agricultural Contracting Update: Contracts in 2008. Ssrn, (72). https://doi.org/10.2139/ssrn.2114442

Mao, H., Zhou, L., Ifft, J., \& Ying, R. Y. (2019). Risk preferences, production contracts and technology adoption by broiler farmers in China. China Economic Review, 54, 147-159. https://doi.org/10.1016/j.chieco.2018.10.014

Mishra, A. K., Kumar, A., Joshi, P. K., \& D'souza, A. (2016). Impact of contracts in high yielding varieties seed production on profits and yield: The case of Nepal. Food Policy, 62, 110-121. https://doi.org/10.1016/j.foodpol.2016.05.005

Mishra, A. K., Kumar, A., Joshi, P. K., D’Souza, A., \& Tripathi, G. (2018). How can organic rice be a boon to smallholders? Evidence from contract farming in India. Food Policy, 75(August 2017), 147-157. https://doi.org/10.1016/j.foodpol.2018.01.007 
OECD/WTO. (2013). Aid for Trade at a Glance: Connecting to Value Chains. Retrieved from OECD Publishing website: http://www.oecd-ilibrary.org/development/aid-for-trade-ata-glance-2007_9789264043220-en

Oya, C. (2012). Contract Farming in Sub-Saharan Africa: A Survey of Approaches, Debates and Issues. Journal of Agrarian Change, 12(1), 1-33. https://doi.org/https://doi.org/10.1111/j.1471-0366.2011.00337.x

Rondhi, M., Imelda, S., Setyawan, H., Aji, J. M. M., Hariyati, Y., Raharto, S., ... Kusmiati, A. (2020). Asymmetric Information And Farmer's Participation In Tobacco Contract Farming. JEJAK: Jurnal Ekonomi Dan Kebijakan, 13(1), 13. https://doi.org/10.15294/jejak.v13i1.17413

Rondhi, M., \& Adi, A. H. (2018). The Effects of Land Ownership on Production, Labor Allocation, and Rice Farming Efficiency. AGRARIS: Journal of Agribusiness and Rural Development Research, 4(2), 101-109. https://doi.org/http://dx.doi.org/10.18196/agr.4265

Rondhi, M., Aji, J. M. M., Khasan, A. F., Putri, A. T. R., \& Yanuarti, R. (2020). Risk Aversion, Risk Preference and Farmers' Decision to Participate in Broiler Contract Farming: A Case Study in Jember, Indonesia. Caraka Tani: Journal of Sustainable Agriculture, 35(1), 98. https://doi.org/10.20961/carakatani.v35i1.37964

Rondhi, M., Khasan, A. F., Mori, Y., \& Kondo, T. (2019). Assessing the Role of the Perceived Impact of Climate Change on National Adaptation Policy: The Case of Rice Farming in Indonesia. Land, 8(5), 81. https://doi.org/10.3390/land8050081

Rondhi, M., Pratiwi, P. A., Handini, V. T., Sunartomo, A. F., \& Budiman, S. A. (2018). Agricultural Land Conversion, Land Economic Value, and Sustainable Agriculture: A Case Study in East Java, Indonesia. Land, 7(4), 148. https://doi.org/10.3390/land7040148

Simmons, P., Winters, P., \& Patrick, I. (2005). An analysis of contract farming in East Java, Bali, and Lombok, Indonesia. Agricultural Economics, 33(SUPPL. 3), 513-525. https://doi.org/10.1111/j.1574-0864.2005.00096.x

Soullier, G., \& Moustier, P. (2018). Impacts of contract farming in domestic grain chains on farmer income and food insecurity. Contrasted evidence from Senegal. Food Policy, 79(September 2017), 179-198. https://doi.org/10.1016/j.foodpol.2018.07.004

Sub-Directorate of Plantation Crop Statistics. (2016). Indonesian Plantations Farm Household Survey $2014 . \quad$ Retrieved from https://mikrodata.bps.go.id/mikrodata/index.php/ddibrowser/705/export/?format=p df\&generate $=$ yes

Suwandari, A., Hariyati, Y., Agustina, T., Kusmiati, A., Hapsari, T. D., Khasan, A. F., \& Rondhi, M. (2020). The Impacts of Certified Seed Plant Adoption on the Productivity and Efficiency of Smallholder Sugarcane Farmers in Indonesia. Sugar Tech, 22(3). https://doi.org/10.1007/s12355-020-00821-2

Väth, S. J., Gobien, S., \& Kirk, M. (2019). Socio-economic well-being, contract farming and property rights: Evidence from Ghana. Land Use Policy, 81(April), 878-888. https://doi.org/10.1016/j.landusepol.2017.04.023 
World Bank. (2008). Agriculture Development. In World Development Report, Agriculture for Development (Vol. 54). https://doi.org/10.1596/978-0-8213-7233-3

Wuepper, D., \& Sauer, J. (2016). Explaining the performance of contract farming in Ghana: The role of self-efficacy and social capital. Food Policy, 62, 11-27. https://doi.org/10.1016/j.foodpol.2016.05.003 